\title{
Geological evidence for paleotsunamis along eastern Sicily (Italy): an overview
}

\author{
P. M. De Martini ${ }^{1}$, M. S. Barbano ${ }^{2}$, D. Pantosti ${ }^{1}$, A. Smedile ${ }^{1}$, C. Pirrotta $^{2}$, P. Del Carlo ${ }^{3}$, and S. Pinzi ${ }^{1}$ \\ ${ }^{1}$ Istituto Nazionale di Geofisica e Vulcanologia, Sezione di Roma 1, Italy \\ ${ }^{2}$ Dipartimento di Scienze Biologiche, Geologiche e Ambientali, Università di Catania, Italy \\ ${ }^{3}$ Istituto Nazionale di Geofisica e Vulcanologia, Sezione di Pisa, Italy
}

Correspondence to: P. M. De Martini (paolomarco.demartini@ingv.it)

Received: 27 January 2012 - Revised: 11 May 2012 - Accepted: 15 May 2012 - Published: 14 August 2012

\begin{abstract}
We present geological evidence for paleotsunamis along the $\sim 230 \mathrm{~km}$-long coast of eastern Sicily (Italy); combining this information with historical data, we reconstruct a unique history of tsunami inundations. We integrate data on 38 paleotsunami deposits (from fine sand layers to boulders) collected at 11 sites (one offshore). The geological data record traces of large tsunamis which have occurred during the past 4 millennia. Chronological constrains include ${ }^{14} \mathrm{C}$, ${ }^{210} \mathrm{~Pb}$ and ${ }^{137} \mathrm{Cs}$, OSL and tephrochronology. When compatible, the age of the paleotsunami deposits is associated to historical events, but it is also used to highlight unknown tsunamis. Average tsunami recurrence interval (between 320 and $840 \mathrm{yr}$ ) and minimum inland tsunami ingressions (often greater than the historical ones) were estimated at several sites. On the basis of this work, the tsunami catalogue is implemented by two unknown tsunamis which occurred during the first millennium $\mathrm{BC}$ and by one unknown regional tsunami, which occurred in 650-770 AD. By including this latter event in the eastern Sicily catalogue, we estimate an average recurrence interval for strong tsunamis of ca. $385 \mathrm{yr}$.

Comparison and merging of historical and geological data can definitely contribute to a better understanding of regional and local tsunami potential and provides robust parameters to be used in tsunami hazard estimates.
\end{abstract}

\section{Introduction}

The critical importance of reliable tsunami hazard assessment models and effective prevention plans were tragically highlighted by the occurrence of the 2004 Sumatra,
2010 Chile and 2011 Japan destructive earthquakes and tsunamis.

Tsunami hazard assessment, early warning systems, as well as prevention and emergency plans have to be based on the knowledge of the potential tsunamigenic sources (of tectonic, volcanic or gravitational origin) of the expected tsunami effects (inundation distance and run-up height) and of their frequency during time. This information is generally extrapolated through the analysis of the historical records describing directly or indirectly the effects of the tsunamis of the past. Historical catalogues of tsunamis (Soloviev et al., 2000; Tinti et al., 2007) are the primary source for describing and modelling the tsunami potential in a specific region.

Unfortunately, for the historical tsunami which occurred before the instrumental era, the association with the causative source is quite difficult and it is generally attempted by modelling extent and distribution of the inundation/run-up values that can only be effective if several observations are available (e.g., Okal and Synolakis, 2004; Gerardi et al., 2008). On the other hand, given the relative rarity of tsunamis, even in areas such as the Mediterranean and Japan where the historical record for large events may go back in time for about two millennia, the historical occurrences of past tsunamis are likely not to be representative of all the possible tsunamis hitting the region. To overcome these actual limitations, during the past decades, approaches based on earthquake geology and paleoseismology (see the pioneering work of Atwater and Moore, 1992) have also been applied to the geological identification and dating of tsunamis of the past (hereinafter paleotsunamis). These approaches allow (i) to extend back in time the tsunami record from a couple to several millennia (Atwater and Hemphill-Haley, 1996; Hutchinson et al., 1997; 
Pinegina and Bourgeois, 2001; Jaffe and Gelfenbaum, 2002; Fujiwara and Kamataki, 2008, among many others), (ii) to confirm and enrich the knowledge of historical tsunamis, and (iii) to discover pre-historical or unknown events. Moreover, the reconstruction of the distribution of the paleotsunami effects can be a critical input to define the causative tsunami source.

The basic principle for the geological identification and dating of paleotsunamis stays on the observation that, when hitting the coast, tsunamis deliver a large amount of sediment (from fine sand to boulders) containing inclusions of marine origin on areas where normal sedimentation is typically continental. For example, following the 2011 tsunami in Japan, sediments including marine debris were found even up to $3 \mathrm{~km}$ inland (Goto et al., 2011). This debris is taken away from the sea bottom and from the shore by the waves approaching and inundating the coast and, because of the decreasing wave energy, deposited inland. The interaction of the waves with the sea bottom produces also important disturbance to the sediments offshore; in case of large tsunami, the sediment remobilization is also due to the backwash during the recession of seawater (Paris et al., 2010 and references therein).

The recognition of any effects caused by a tsunami in the sedimentation and stratigraphy of a coastal area forms the geological record of the paleotsunami and provides information about the minimum inundation extent, minimum elevation reached by the sea wave, and age of the event; data to be used as an integration of the tsunami historical catalogue.

Several catalogues have been published on the tsunamis that affected the Mediterranean coasts in the past (e.g., Soloviev et al., 2000; Tinti et al., 2007). These cover about $2000 \mathrm{yr}$ of history, with various degrees of completeness for different periods and areas. Italy and Greece are the Mediterranean countries with the highest known number of tsunamis. Eastern Sicily is one of the most tsunami-prone regions of Italy. In fact, because of its location, it can experience not only the effects of the relevant local tsunamigenic sources, but also the effects of tsunamis originated by distant sources, such as those belonging to the Aegean subduction zone (Fig. 1). Further tsunamigenic potential is represented by the several active volcanoes located along the coast or offshore (Fig. 1) as well as by the submarine landslides.

Nowadays, the eastern Sicily coastal area is densely populated with numerous large cities overlooking the Ionian Sea, historical and archaeological sites punctuating the coastline along with industrial centres and military bases. All this highlights the urge for a detailed analysis of the actual tsunami hazard/risk and for the establishment of effective prevention measures.

With the aim of contributing to a better understanding of the tsunami potential of eastern Sicily, this paper integrates a unique set of published data on paleotsunami deposits recently collected by different authors along the $\sim 230 \mathrm{~km}$ stretch of coast facing the Ionian Sea. This reviewing effort

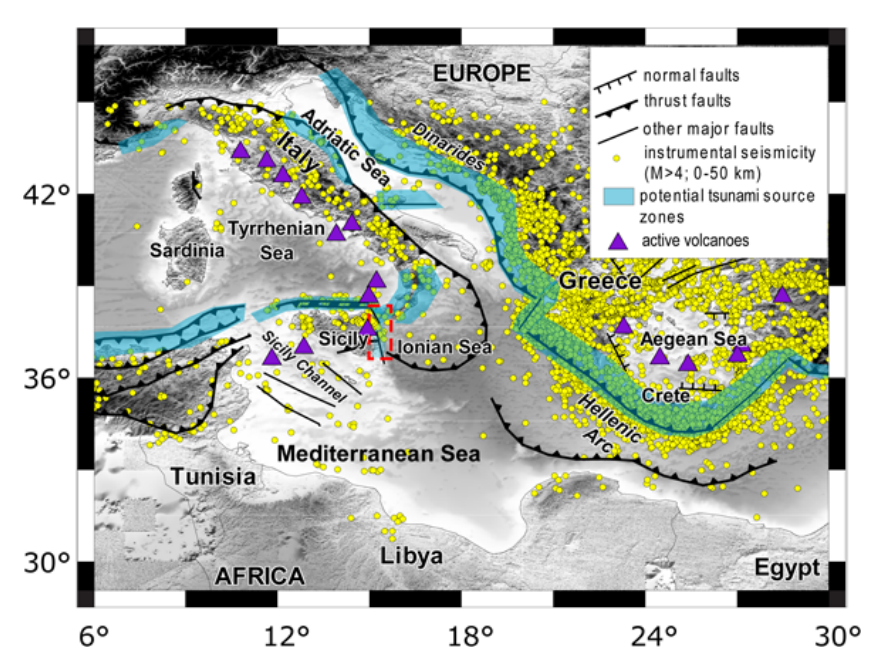

Fig. 1. Tectonic sketch map of the central-eastern Mediterranean basin. The red dashed rectangle locates the study area. Instrumental seismicity (yellow dots; $M>4$; depth $0-50 \mathrm{~km}$ ) is taken from the ISC Catalogue (ISC, 2004). Colour-shaded zones highlight the main structures capable of generating tsunamis that pose a significant hazard to Mediterranean shore-facing settlements (modified after Lorito et al., 2008). Active volcanoes are taken from the database developed within the EU TRANFER Project STREP (n. 037058).

is attempted for the first time in Sicily thanks to a significant number of recently published studies. Historical and geological evidence for paleotsunamis is used to reconstruct a history of tsunami inundations in the region, to highlight potential inundation extents and also to discriminate the nature of the causative sources, local, regional or basin-wide.

\section{Methods}

Published data from the co-authors of this work are used to compile a homogeneous and integrated history of tsunami inundations in eastern Sicily (Pantosti et al., 2008; Barbano et al., 2009, 2010; De Martini et al., 2010; Smedile et al., 2011; Gerardi et al., 2012). Only in the discussion chapter, will we also integrate data from other authorships (Scicchitano et al., $2007,2010)$. This is to preserve the homogeneity of the approach and the "safe" integration and correlation of the data. With the aim of recognising and dating paleotsunami deposits, in the above mentioned papers we applied an original combination of historical, archeological, geomorphological, stratigraphic, paleontologic and geochronologic approaches developed both in the field and laboratories. This method was set to recognise and characterise high-energy marine deposits that are allochthonous to most of the stratigraphy and show morphologic, sedimentologic and paleontological characteristics compatible with the tsunami action/modification. The most common paleotsunami deposit is represented by a thin layer of sand, coarse sand or pebbles, with sharp basal contact containing shell debris, marine benthic and planktonic 
foraminifera and vegetal remains. These layers are sandwiched between low-energy continental deposits with distinct faunal associations (see e.g., De Martini et al., 2010 and references therein). Also boulders may be detached and transported from a submerged rock platform and deposited inland (Barbano et al., 2010 and references therein). Offshore signatures of paleotsunamis were also recognised thanks to a novel approach identifying, as paleotsunami proxies, rare layers of displaced fauna (i.e., not consistent with the water depth of the sampling site) coupled with the concentration of vegetal remains and peculiar sedimentary changes, sandwiched in very low-energy mud deposits (for details see Smedile et al., 2011).

In this paper, we discuss results from a total of 69 cores collected through hand- or engine-coring inland and 1 pistoncoring offshore. They were sampled from 7 different sites inland and 1 site offshore, distributed along a $230 \mathrm{~km}$-long coastline (Fig. 2). In order to identify the most favourable traps for tsunami deposits, coastal sampling sites were selected on the basis of historical knowledge of tsunamis of the past (Gerardi et al., 2008; Barbano et al., 2009 and references therein), integrated with a detailed analysis of the coastal geology and geomorphology (De Martini et al., 2010). Offshore, the focus was given to the sampling of a potentially complete and undisturbed stratigraphic record in a low-energy, low-erosion and low-modification area where only exceptional high-energy signatures could be found. For this selection, a closely spaced grid of seismic reflection chirp-sonar profiles covering $150 \mathrm{~km}^{2}$ was used (Smedile et al., 2011).

The approach followed in the study of all the collected sediments was the same, so that the dataset can be considered homogeneous. All the cores where visually inspected and sampled for sedimentological, petrographic, paleontological and geochronological characterisation. Anomalous allochthonous layers considered possible evidence for paleotsunami inundations were investigated in detail and chronologically constrained on the basis of radiocarbon dating, short-lived radionuclides, optically stimulated luminescence and tephrochronology. When enough data were available, age models were built and sedimentation rates extrapolated. The sediments interpreted as paleotsunamis at each site are used to define tsunami recurrence, inundation distances, along-coast spatial distributions and ages of tsunamis of the past.

Moreover, displaced boulders were studied at 1 site by field survey mapping and following elaboration through a hydrodynamic approach (Barbano et al., 2010).

The main uncertainty with coarse layers, both inland and offshore but also with boulders, is whether they are deposited because of a tsunami or by storm waves. An extended discussion about this issue can be found in Weiss and Bahlburg (2006), Morton et al. (2007), Barbano et al. (2010), De Martini et al. (2010) and Smedile et al. (2011). In most of the cases, a storm source for the marine deposits found

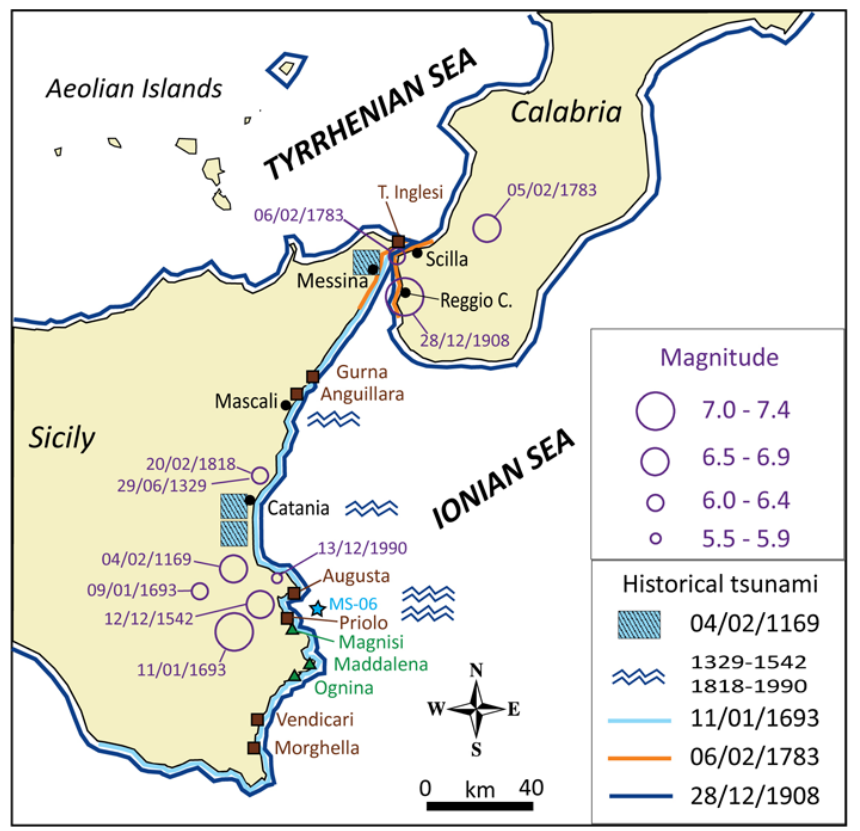

Fig. 2. Map of eastern Sicily showing the main tsunamigenic earthquakes which occurred in historical time and inundated areas by the most energetic regional tsunamis (modified from Gerardi et al., 2012). Mascali, Catania and Augusta were also affected by the 1329, 1818, 1542 and 1990 local tsunamis (wavy symbol), respectively (see Table 1). Scilla and Torre Faro are related to the 1783 tsunami probably triggered by a submarine landslide (e.g., Gerardi et al., 2008; Bozzano et al., 2011). Investigated sites are shown with brown squares and with green triangles when studied by our group or by other researchers, respectively. The light blue star shows the location of the long sediment gravity core (MS-06).

in our inland cores could be excluded because the sampling sites presented in this work are located at a greater distance from the coastline with respect to the maximum calculated storm inundation distance of about 40-60 m (De Martini et al., 2010; Barbano et al., 2010; Gerardi et al., 2012). In fact, in order to avoid the area of influx of storm waves (Morton et al., 2007) that often coincide with a zone of erosion/bypass by tsunamis (Gelfenbaum and Jaffe, 2003), the sites selected for coring are located at a minimum distance of 150-200 m from the present shoreline. Offshore, storms signatures are restricted to the near-shore area only (a few hundreds of $m$ from the coastline), that is not the case of the offshore site included in this work that is located at more than $2 \mathrm{~km}$ from the coastline (Fig. 2). Moreover, storm deposits would have to be much more frequent with respect to the limited number of marine inundation events we have found, because storms occur much more frequently than tsunamis (e.g., De Martini et al., 2010). The hypothesis that these signatures are likely to represent tsunamis of the past becomes stronger when we compared the age of the well-known historical tsunamis with the geologic age ranges defined for the paleotsunami deposits and found a striking agreement. 
Table 1. Historical tsunamis affecting the coast of eastern Sicily (data from Boschi et al., 2000; Tinti et al., 2007; Gerardi et al., 2008; Barbano et al., 2009 and references therein).

\begin{tabular}{lll}
\hline Date & Source & Hit localities/areas \\
\hline ca. 1600 BC & Santorini volcanic explosion & East Mediterranean \\
1st century (17 AD?) & unknown & Sicily \\
365 July 21 & Crete-Gortyna quake & Sicily and other islands \\
1169 February 4 & South-eastern Sicily quake & Messina, Catania, Sicily \\
1329 June 29 & Etna eruption and quake & Mascali (eastern Sicily) \\
1542 December 12 & South-eastern Sicily quake & Augusta \\
1693 January 11 & South-eastern Sicily quake & Eastern Sicily and Malta \\
1783 February 5-6 & Southern Calabria's quakes and landslide & Torre Faro, Messina, Scilla and Southern Calabria \\
1818 February 20 & Eastern Sicily quake & Catania \\
1908 December 28 & Messina Straits quake & Eastern Sicily and Southern Calabria, Malta \\
1990 December 13 & South-eastern Sicily quake & Augusta \\
\hline
\end{tabular}

\section{Historical record}

Eastern Sicily was chosen for our investigations because it was affected in historical times by large earthquakes followed by devastating tsunamis (Fig. 2). A wealth of historical accounts is available describing hit localities, inundation areas and run-up heights and these records were used as a first input for selecting sites where to start the geological investigations of paleotsunami deposits.

A list of events (Table 1) on already known tsunamis together with their most probable triggering phenomenon (earthquake, landslide and volcanic eruption) and hit coastal areas, was arranged on the basis of historical compilations (Boschi et al., 2000; Tinti et al., 2007; Gerardi et al., 2008; Barbano et al., 2009 and references therein).

The dataset with information on hit localities, inundation areas and run-up heights can be considered complete only for the past millennium (e.g., Gerardi et al., 2008) because for the oldest events their accounts are scant. The analysis of the affected areas from the historical reports allows a first-hand discrimination of the different tsunami causative sources. The events hitting restricted areas are defined as local ones (17 AD, 1329, 1542, 1783, 1818 and 1990 tsunamis), whereas those that struck the entire eastern coast of Sicily, with waves also observed as far as the Aeolian Islands, southern Sicilian coast, Malta Island and Calabria are defined as regional ones (1169, 1693 and 1908) (e.g., Barbano et al., 2009). A few data are available also for the basin-wide ca. 3600 BP Santorini and 21 July 365 Crete tsunamis. The paroxysmal eruption of Santorini (known also as the Late Bronze Age or LBA eruption) was very large and appears to have generated multiple tsunamis that involved a large part of the eastern Mediterranean (Dominey-Howes, 2004 and reference therein). The 365 A.D. earthquake was located in Crete (e.g., Stiros, 2001), but according to written sources and archaeological data (Guidoboni et al., 1994), its tsunami effects were observed in continental Greece, Adriatic Sea, Sicily and North Africa.
On the basis of the available historical data (Table 1), we may estimate an average tsunami recurrence interval for the whole coast of eastern Sicily. To do this, and considering that the degree of completeness depends on the period of the catalogue we consider, using the past 1 or $2 \mathrm{ka}$ we obtain values of ca. 120 and $220 \mathrm{yr}$, respectively.

\section{Investigated sites}

A summary of the characteristics and results obtained in all the sites (Fig. 2) from which there is evidence for tsunami deposits is presented in the following. For each site, we discuss the general geomorphic setting, number and characteristics of layers interpreted as tsunami deposits, their ages, the maximum investigated depth and relative age, the minimum distance from the present shoreline (being related to the presence of a tsunami deposit and knowing that the Holocene sealevel was lower with respect to its present position, this value should be considered as a minimum), the average tsunami recurrence interval (ATRI hereinafter, calculated taking into account the age of the associated historical events) and any other information if available (Table 2). More details for each site can be found in the referred papers. The sites are described from north to south.

\subsection{Torre degli inglesi site (Tor)}

Torre degli Inglesi is a defense tower first built in Roman times (1st century BC - Fig. 2). Its main building sits on a local height, about $5 \mathrm{~m}$ above sea level (a.s.l. hereinafter), and about 40 to $80 \mathrm{~m}$ from the present shoreline, behind the sand dunes bounding the beach. Pantosti et al. (2008) studied and sampled stratigraphic sections of the $3 \mathrm{~m}$ deep excavation made by the Superintendence of Messina at this site. Stratigraphic, grain-size, macrofaunal and micropaleontologic analyses support the hypothesis that two distinct sandy layers (characterised by fragments of mollusks and corals, rare benthonic and planktonic foraminifera), totally 
Table 2. Summary of the main collected data. Please note that at Torre degli Inglesi and Vendicari sites the working approach did not involve coring, but the study of an archaeological exposure and boulders, respectively. The number with * in the Vendicari line indicates the number of studied boulders. Average Tsunami Recurrence Interval is shown with the acronym ATRI (penultimate column). The tsunami identification criteria are shown in the last column with the following keys: $\mathrm{S}$ - stratigraphic, $\mathrm{G}$ - grain size, $\mathrm{M}$ - macrofauna, F - foraminifera, D - distance from the coastline, $\mathrm{H}$ - if the tsunami deposit age is compatible with an historical event.

\begin{tabular}{lrrrrrrrl}
\hline $\begin{array}{l}\text { Site } \\
\text { name }\end{array}$ & $\begin{array}{r}\text { Cores } \\
\text { Cores }\end{array}$ & $\begin{array}{r}\text { Max } \\
\text { depth }(\mathrm{m})\end{array}$ & $\begin{array}{r}\text { C14 (OSL) } \\
\text { dating }\end{array}$ & $\begin{array}{r}\text { Max age/depth } \\
\left(\mathrm{yrBPm}^{-1}\right)\end{array}$ & $\begin{array}{r}\text { Min inund. } \\
\text { dist. (m) }\end{array}$ & $\begin{array}{r}\text { Tsuna } \\
\text { deps }\end{array}$ & $\begin{array}{r}\text { ATRI } \\
\text { (yr) }\end{array}$ & $\begin{array}{l}\text { Ident. } \\
\text { criteria }\end{array}$ \\
\hline T. Inglesi (Tor) & & 3.0 & 6 & $2100 / 3.0$ & 80 & 2 & & S G M F H \\
Gurna (Gur) & 4 & 4.2 & 1 & $4300 / 4.0$ & 340 & 4 & 1330 & S G D H \\
Anguillara (Ang) & 3 & 5.2 & 1 & $600 / 3.6$ & 280 & 3 & 180 & S G M D H \\
Augusta (Au) & 6 & 4.3 & 5 & $3000 / 2.0$ & 460 & 3 & 870 & S G M F D H \\
Augusta off (AuOff) & 1 & 6.7 & 10 & $4500 / 6.6$ & & 12 & 320 & S G M F D H \\
Priolo (Pr) & 16 & 4.2 & 3 & $4100 / 1.6$ & 530 & 4 & 1100 & S G M F D H \\
Vendicari (Ven) & $175 *$ & & 3 & & 55 & 2 & & S M D H \\
Morghella (Mor) & 40 & 5.8 & $8(4)$ & $5200 / 4.2$ & 1200 & 2 & & S G M F D H \\
Gurna - Anguillara & 7 & 5.2 & & & 340 & 6 & 840 & \\
Augusta - Priolo & 22 & 4.3 & & & 530 & 7 & 550 & \\
\hline
\end{tabular}

different from most of the deposits outcropping on the archeological sections, were deposited by paleotsunami inundations at this site (TOR-T1 and TOR-T2). Six radiocarbon samples and several archeological estimates constrain the age of the two tsunami events (Table 2) in the intervals 3351861 AD for TOR-T1, with the younger part of the interval as preferred, and $0-125 \mathrm{AD}$ for TOR-T2. The authors suggest that the age of TOR-T2 layer is consistent with the $17 \mathrm{AD}$ event, known as the Reggio Calabria earthquake that may have produced a tsunami too, while TOR-T1 is tentatively associated to the 6 February 1783 event, known as the Scilla earthquake and tsunami (Fig. 2b).

\subsection{Gurna site (Gur)}

The Gurna site is a fresh-water shallow pond, protected from the sea by ca. 3-5 m-high sand dunes and located as far as $340 \mathrm{~m}$ from the present shoreline (Fig. 2). Barbano et al. (2009) investigated this site by means of 4 cores sampling the stratigraphy down to a maximum depth of $4.2 \mathrm{~m}$ (Table 2). Within the local silty and clayey stratigraphic sequence four distinct coarser layers, from sandy silt to coarse sand, were found and interpreted as paleotsunami deposits on the basis of stratigraphic and grain-size analyses (GUR-T1 to GUR-T4). One radiocarbon sample, collected within the deepest layer at about $4 \mathrm{~m}$ of depth, constrains the occurrence of the four hypothesized tsunamis within the past $4000 \mathrm{yr}$. Assuming limited erosion and continuous sedimentation, the local average sedimentation rate results to be $0.9 \pm 0.1 \mathrm{~mm} \mathrm{yr}^{-1}$. On this basis, the four tsunami events occurred in the following time windows: 1390-1780 AD (GUR-T1); 650-1050 AD (GUR-T2); 100600 AD (GUR-T3); 2310-2140 BC (GUR-T4). The authors highlight that the age of GUR-T3 deposit is consistent with the 365 AD tsunami, while GUR-T2 and GUR-T1 deposits are tentatively associated to the 1169 and 1693 tsunamigenic earthquakes, respectively. An average tsunami recurrence interval (ATRI) of about $1330 \mathrm{yr}$ can be estimated for this site.

\subsection{Anguillara site (Ang)}

The Anguillara site is located on a relatively flat area $280 \mathrm{~m}$ from the present shoreline (Fig. 2), protected from the sea by ca. $3-5 \mathrm{~m}$-high sand dunes. The flat is dominated by low-energy alluvial deposition, most probably related to the nearby Macchia stream overbank episodes. Barbano et al. (2009) investigated this site by means of 3 cores down to a maximum depth of $5.2 \mathrm{~m}$. Based on stratigraphic, grainsize and macrofaunal analyses, the local stratigraphy, mainly composed by gray clay and brownish silt, appears interrupted by two different coarser layers, made by fine sand to sand, and by a peculiar detritic deposit (with a few echinoderm fragments), all interpreted as left by tsunami inundations (ANG-T1 to ANG-T3). One radiocarbon sample, collected below the detritic layer at about $3.6 \mathrm{~m}$ of depth, is used to constrain the occurrence of the 3 tsunami layers (Table 2) within the past 6 centuries. Assuming limited erosion and continuous sedimentation, a local average sedimentation rate of $6-7 \mathrm{~mm} \mathrm{yr}^{-1}$ can be obtained. On this basis, the ages of the three tsunami events are comprised in the following time windows: 1880-1920 AD (ANG-T1); 1660-1710 AD (ANG-T2); 1425-1510 AD (ANG-T3). The authors hypothesize that these three deposits could be well related to the tsunamis originated by the 1542, 1693 and 1908 earthquakes, respectively. For this site, an ATRI of about $180 \mathrm{yr}$ can be calculated.

\subsection{Augusta site (Au)}

The Augusta site is located in the northern portion of the $\mathrm{Au}-$ gusta Bay (Fig. 2), on an alluvial surface gently dipping to 
the SW, towards a large salt marsh bounding the sea, at an elevation of 1 to $5 \mathrm{~m}$ a.s.l. In this site, De Martini et al. (2010) dug 6 cores down to a maximum depth of $4.3 \mathrm{~m}$ and at a maximum distance of $460 \mathrm{~m}$ from the present sea coastline (Table 2). The site stratigraphy, investigated by means of stratigraphic, grain-size and micro-macrofaunal analyses, appears related to an alluvial environment and is characterised by an alternation of low-energy silty clay, clayey silt and silt deposits, sharply contrasting with two high-energy coarse (both bioclastic and detritic) layers of clear marine origin, as highlighted by planktonic and marine benthic foraminifera found, thanks to detailed micropaleontological analysis. These two deposits together with a sharp change from alluvial to marine environment were interpreted as resulting from three paleotsunami inundations (AU-00 to AU-02, see Fig. 3a).

Five radiocarbon samples, collected from about $2.0 \mathrm{~m}$ of depth, constrain the deposition of this sequence during the past $3000 \mathrm{yr}$ and suggest that 3 tsunami events occurred in the following time windows: 650-770 AD (AU-00); 600$400 \mathrm{BC}$ (AU-01); 975-800 BC (AU-02). An ATRI of about $870 \mathrm{yr}$ can be obtained for this site.

\subsection{Augusta offshore site (AuOff)}

The study of an offshore site was conceived with the idea to search for possible signatures in the sediment, fauna, physical properties, etc., that could be related to the occurrence of a tsunami and to test these results versus the historical record.

The Augusta Bay was considered favourable for this experiment, as it is a protected, $15 \mathrm{~km}$ wide, ca. $25 \mathrm{~km}$ long engulfment with no important drainage discharge from the inland. Its morphobathymetry is rather smooth, with maximum depths reaching $120-150 \mathrm{~m}$ at the shelf-break that is located approximately $7 \mathrm{~km}$ offshore. A detailed analysis of a close-spaced grid of newly acquired seismic reflection chirpsonar profiles, covering most of the bay, guided Smedile et al. (2011) to the selection of a coring site. This focused on a low energy area where to collect potentially undisturbed sediments, far from areas affected by relevant erosional and depositional processes related to currents, gravitational failures, or human activities. A $6.7 \mathrm{~m}$ long sediment gravity core (MS06) was collected in the northern part of the gulf (Fig. 2), about $2.3 \mathrm{~km}$ off the coastline, at a water depth of $72 \mathrm{~m}$. Smedile et al. (2011) proposed that twelve high-energy layers, defined on the basis of high concentration of displaced epiphytic foraminifera (benthic species growing in vegetated substrates like the Posidonia oceanica) coupled with grainsize changes (very detailed sedimentological analysis was performed thanks to intense use of a laser particle counter) and presence of abundant vegetal remains, are the evidence for the occurrence of the same number of high-energy exceptional events able to disperse an extra amount of infralittoral epiphytic species toward deeper areas. Tsunami backwash is considered as best candidate. Ten radiocarbon samples, the radioactive tracers ${ }^{210} \mathrm{~Pb}$ and ${ }^{137} \mathrm{Cs}$ for the top core and the
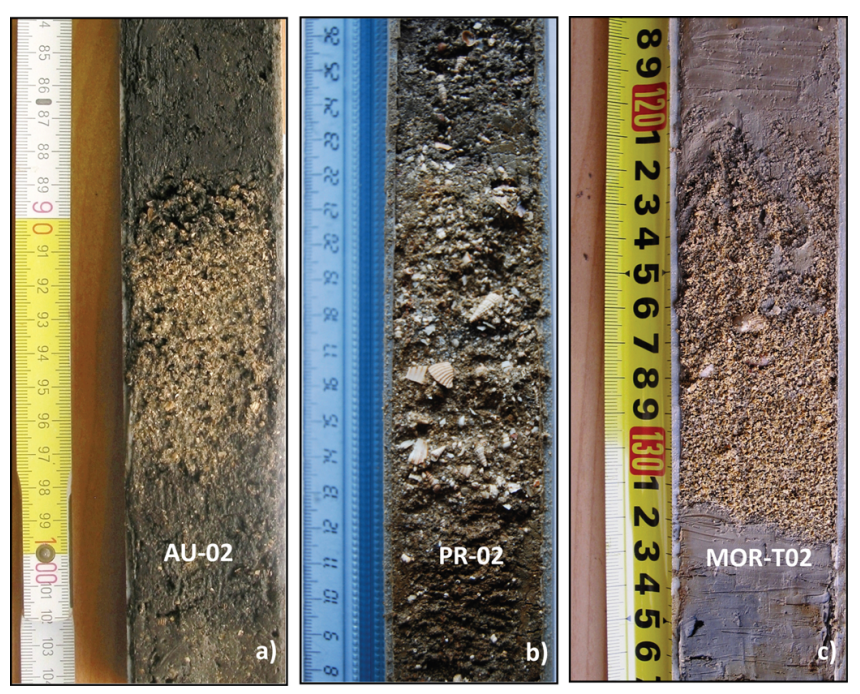

Fig. 3. From left to right, pictures of three distinct tsunami deposits found at the Augusta, Priolo and Morghella sites, respectively. These three layers share some stratigraphical and sedimentological characteristics indicative of a tsunami origin sensu Morton et al. (2007). In fact, they appear as relatively thin $(<25 \mathrm{~cm})$, single, massive and structureless beds with abrupt, often erosional, lower contact.

correlation of one tephra layer found at ca. $3 \mathrm{~m}$ of depth with the fallout deposit produced by the $122 \mathrm{BC}$ Plinian eruption of Etna volcano, constrain the age of sedimentation of the whole core within the past $4500 \mathrm{yr}$ and are used to estimate the age of the 12 events (AuOFF-En). These occurred in the following time windows: 1820-1920 AD (E1); 1430-1810 AD (E2); 930-1170 AD (E3); 590-800 AD (E4); 430-660 AD (E5); 90-370 AD (Ex); 350-130 BC (E6); 580320 BC (E7); 660-400 BC (E8); 800-560 BC (E9); 1130810 BC (E10); 1720-1200 BC (E11). To these authors, the hypothesis that these layers are the signature of tsunamis of the past is also supported by the agreement between the age interval of the three youngest high-energy events (E1, E2, E3) and the age of regional historical tsunamis (1908, 1693 and 1169 events). Moreover, two more events (Ex and E11) may be well correlated in age to basin-wide events such as the 365 AD Crete earthquake and the ca. 3600 BP Santorini explosion, respectively. An ATRI of about $320 \mathrm{yr}$ can be calculated for this site (Table 2).

\subsection{Priolo site $(\operatorname{Pr})$}

The Priolo site is located within a shallow coastal lagoon protected from the sea by a ca. $4.5 \mathrm{~m}$-high bar of sand dunes (Figs. 2 and 4a). At this location, De Martini et al. (2010) dug 16 cores down to a maximum depth of $4.2 \mathrm{~m}$ and at a maximum distance from the sea of $530 \mathrm{~m}$. The stratigraphic, grain-size and paleontological (mollusks and foraminifera) analyses performed at this site indicate that the whole sedimentary sequence belongs to a lagoonal 

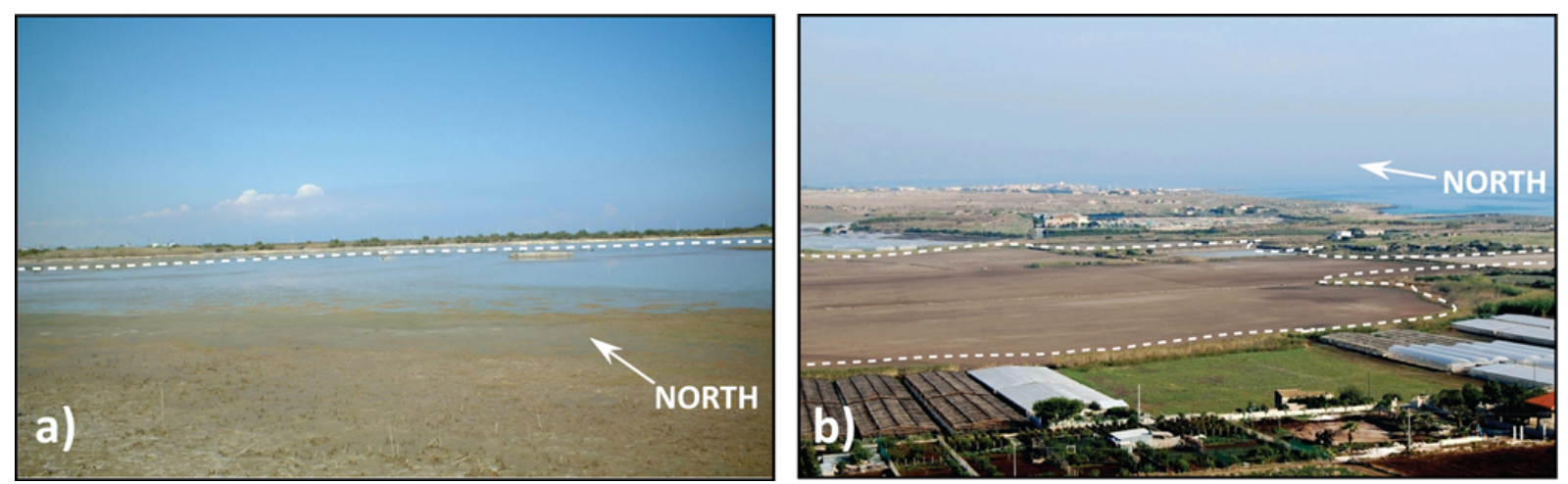

Fig. 4. View of the Priolo (a) and Morghella (b) sites, the white dashed line marks the edges of the almost flat area.

low-energy environment with few exceptions represented by 4 distinct high-energy (bioclastic and sandy) layers of marine origin (PR-01 to PR-04), containing an abnormal concentration of shell fragments and whole gastropods, planktonic foraminifera and an unusual increment in the benthic foraminiferal specific diversity, and then interpreted as due to paleotsunamis (Table 2). Three radiocarbon samples, collected down to about $1.6 \mathrm{~m}$ of depth, and the correlation of the tephra layer recovered at ca. $0.7 \mathrm{~m}$ of depth with the fallout deposit produced by the $122 \mathrm{BC}$ Plinian eruption of Etna volcano, constrain the lagoonal sedimentation within the past $4100 \mathrm{yr}$ and suggest that the 4 events occurred in the following time windows: slightly younger than 1420 1690 AD (PR-01); 160-320 AD (PR-02, see Fig. 3b); 800600 BC (PR-03); 2100-1635 BC (PR-04). The authors infer that three of them can be associated with historical tsunamis and specifically PR-01 can be related to the 1693 earthquake, PR-02 can be linked to the 365 AD Crete earthquake and PR04 could be tentatively associated with the $\sim 3600$ BP Santorini event; differently PR-03 has not a potential correspondence with an historical event. An ATRI of about $1100 \mathrm{yr}$ can be estimated for this site.

\subsection{Vendicari site (Ven)}

The Vendicari site is located on a $50-70 \mathrm{~m}$ wide wave-cut platform, reaching a maximum elevation of $5 \mathrm{~m}$ a.s.l., characterised by significant roughness and no vegetation (Fig. 2). Barbano et al. (2010) studied size, shape, position, pretransport setting and long-axis orientation of 175 boulders (up to $27 \mathrm{t}$ in mass) (Fig. 5). Of the analysed megaclasts, only those sited beyond the transport distance limit of the local possible maximum-recorded storm waves (calculated to be about $40 \mathrm{~m}$ from the shoreline) were considered and interpreted as potentially left by paleotsunamis. Assuming that the age of marine shells living attached to the boulders represents the age of the occurrence of the wave that moved them from the underwater rocky coast and deposited at the present location, three radiocarbon samples, collected from different boulders, suggest the occurrence of two events of emplacement in the following time windows (Table 2): 1700-1950 AD (VEN-01); 660-940 AD (VEN-02). For the most recent event the authors propose a possible correlation with the 1908 or 1693 tsunamigenic earthquakes, with the latter preferred, being the strongest in the study area.

\subsection{Morghella site (Mor)}

The Morghella site (Fig. 2) is placed on a flat wetland, up to $1.3 \mathrm{~km}$ long and $0.8 \mathrm{~km}$ wide (Fig. $4 \mathrm{~b}$ ), partially submerged from October to July. An approximate $3 \mathrm{~m}$-high moderately cemented fossil dune separates the wetland from the coast creating a restricted environment. Today, the only potential connection to the sea is through an artificial narrow channel cut at the beginning of the 20th century for saltpan works. Gerardi et al. (2012) dug 40 cores down to a maximum depth of $5.8 \mathrm{~m}$ and at a maximum distance of $1200 \mathrm{~m}$ from the sea (Table 2). The pond is characterised by a lagoonal finegrained stratigraphic sequence dominated by clay and siltyclay deposits. Within this quite monotonous sequence, two abrupt changes in grain size occur. These are identified by two distinct coarse yellow sandy levels of clear marine origin, showing abundant marine shell debris and increased diversity in the foraminiferal assemblage (based on macrofaunal and micropaleontological analyses) and, thus, interpreted as the record of two paleotsunamis (MOR-T01 and MORT02, Fig. 3c). Eight radiocarbon samples, collected down to about $4.2 \mathrm{~m}$ of depth, and four OSL measurements of samples collected within the high-energy sandy layers, provided a good chronological framework and constrain the sedimentation of the sequence within the past $5200 \mathrm{yr}$. Combining all the chronological data, the two events occurred in the following time windows: 1870-1930 AD (MOR-T01); 270$500 \mathrm{AD}$ (MOR-T02). Based on these ages, the authors suggest that the MOR-T01 and MOR-T02 deposits are correlated with the 1908 AD Messina Strait and the 365 AD Crete tsunamigenic earthquakes. 

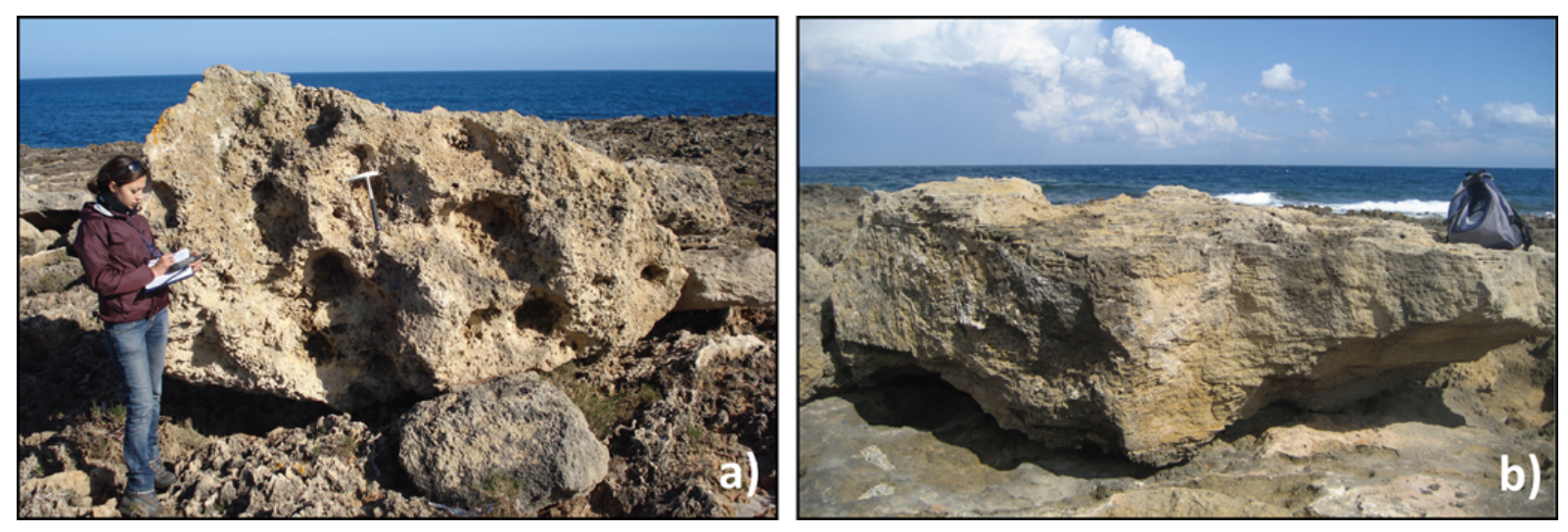

Fig. 5. Pictures of two (a, b) boulders, found at Vendicari site, lying at a distance beyond the limit of the local maximum-expected storm waves and interpreted as deposited by tsunamis.

\section{Combination of results and discussion}

The data presented in the previous chapter are summarized in Table 2. We integrated information from a single $6.7 \mathrm{~m}$ long offshore piston core and 69 inland boreholes down to a maximum depth of $5.8 \mathrm{~m}$, from an archeological exposure, and from 175 displaced boulders, spanning in time from $5200 \mathrm{yr}$ BP to the present. From these data, we found evidence for 32 tsunami deposits at 8 different sites, with a maximum inundation distance from the present coastline of $1200 \mathrm{~m}$ (at the Morghella site). The age of these events is constrained thanks to $37{ }^{14} \mathrm{C}$ and 4 OSL datings, together with tephrochronology and archeological estimates (at the Torre degli Inglesi site). We calculated the ATRI for every site in which three or more tsunami layers were found and we obtained values ranging between 180 and $1330 \mathrm{yr}$.

These ATRIs can be refined if we consider that the Gurna and Anguillara sites, but also the Augusta and Priolo sites, are located close to each other, share a similar geomorphological setting, were likely inundated by the same tsunamis and, thus, their relative tsunami inundation history can be expected to be the same. On this basis, we merged results from the two adjacent sites assuming that the lack of a tsunami layer at one site is related to a specific local situation preventing deposition at the time of the event or because of variable distribution of sediments, erosion, backwash, etc. Following this reasoning (Table 2 lower part), a new ATRI for Gurna and Anguillara sites of $840 \mathrm{yr}$ ( 6 events from $2310 \mathrm{BC}$ to 1908 AD) and for Augusta and Priolo sites of $550 \mathrm{yr}$ (7 events from ca. $1600 \mathrm{BC}$ to $1693 \mathrm{AD}$ ) was calculated. This yields a refined ATRI estimate for the eastern coast of Sicily that ranges between 320 and $840 \mathrm{yr}$.

In order to compile a complete dataset of all the sites where geological evidence for a tsunami inundation was found along the eastern Sicilian coast, we included also the results by Scicchitano et al. $(2007,2010)$ from the Magnisi and Maddalena Peninsula and from Ognina (for sites location see Fig. 2).
Scicchitano et al. (2007) presented a detailed work done on about 55 scattered boulders found on rocky platforms in the northeastern sector of the Magnisi Peninsula (just in front of the Priolo site, presented above), in the northeastern sector of the Maddalena Peninsula and at Ognina (the latters ca. 5 and $20 \mathrm{~km}$ south of Siracusa, respectively). The authors focused on a hydrodynamic approach used to determine whether tsunami- or storm-generated waves were responsible for coastal boulder deposition. They suggest that three historical tsunamis are responsible for the detachment and transport of the largest boulders. An interpretation of some ${ }^{14} \mathrm{C}$ datings was the basis for the attribution of these events to the 1908 (Maddalena Peninsula), 1693 (Magnisi and Maddalena Peninsulas), and 1169 (Ognina) historical tsunamis.

Scicchitano et al. (2010) present sedimentological and palaeoecological observations that support the relation between some deposits, found on a natural exposure along the channel of Ognina, to tsunami events. Thanks to archaeological determinations and radiocarbon dating on marine organisms the coarse deposits occurring in the Ognina section were likely related to the 1693, 1169 and $365 \mathrm{AD}$ tsunamis.

Figure 6 was conceived to better compare all the recognised tsunami deposits and visualise their possible correlations. We plotted paleotsunami age ranges vs. the location of the sites where they were found along the eastern Sicilian coast; on the same plot we added also the extent of coastline known to be inundated during the historical tsunamis. The integration of all existing data for this stretch of Sicilian coast provides a unique reference (1) to test if the age interpretations made by the different authors are coherent, and (2) to evaluate the minimum extent of coastline hit by each correlated event.

Focusing only on the six minor historical tsunamis, Fig. 6 shows that the 1990, 1818 and 1329 deposits were not found even in the areas where witnesses described the water flooding and the chance that any other tsunami deposits found at other sites would represent their geological signature is small 


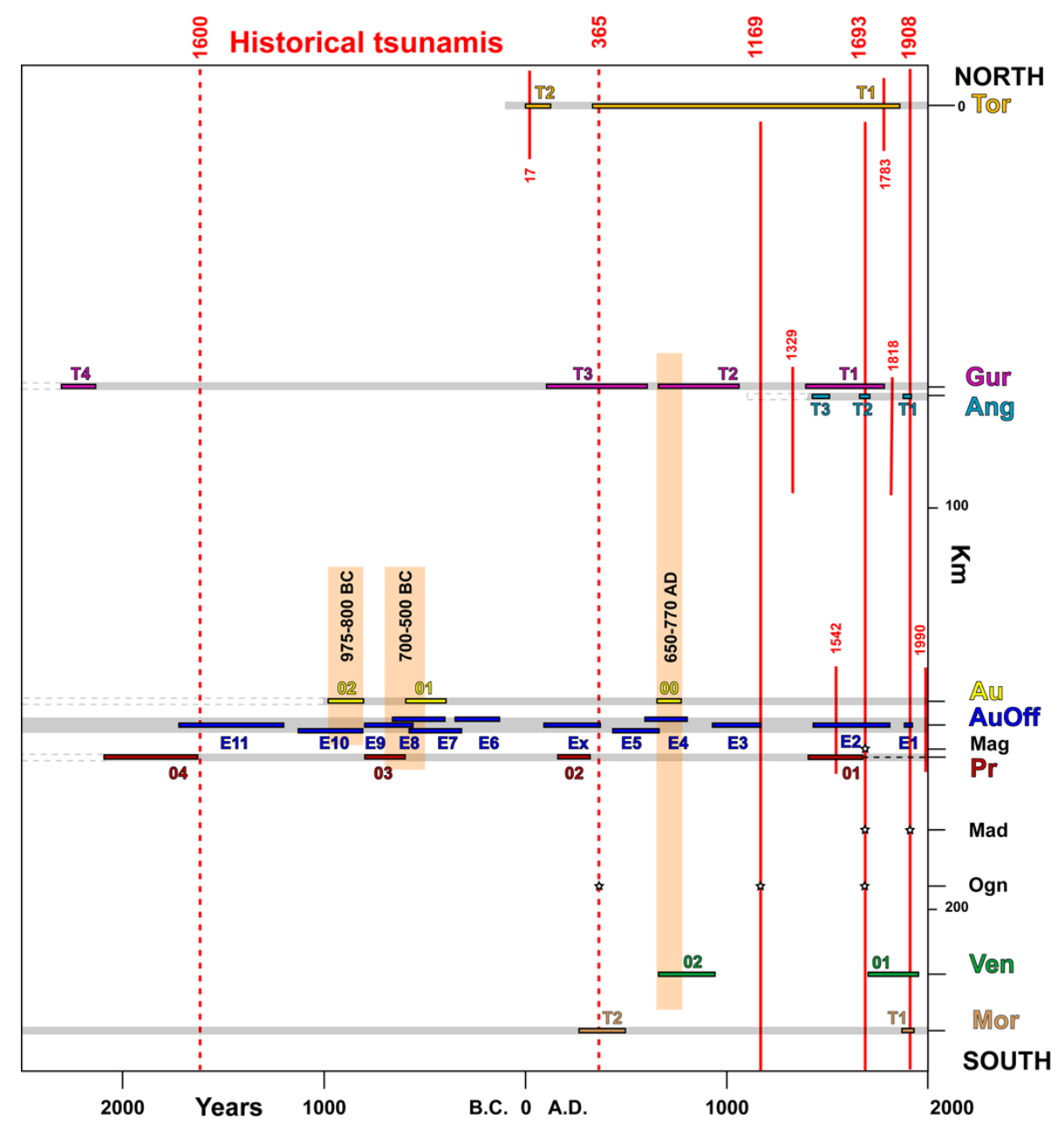

Fig. 6. Space-time plot of the tsunamis identified along the coast of eastern Sicily. The distance (km) from the northern tip to the southern one of the rectified coastline is on the $\mathrm{y}$-axis, while time (years) is on the $\mathrm{x}$-axis. The eight sites investigated by our group (Tor = Torre degli Inglesi; Gur = Gurna; Ang = Anguillara; Au = Augusta; AuOff = Augusta Offshore; Pr = Priolo; Ven = Vendicari; Mor = Morghella) are shown with different colours while the three sites (Mag= Magnisi P.; Mad=Maddalena P.; Ogn= Ognina) studied by Scicchitano et al. $(2007,2010)$ are shown in black. The horizontal coloured bars are the age intervals of the tsunamis (Scicchitano et al., 2007,2010 events are marked with a star); horizontal light gray bars represent the time interval investigated at each site, it is dashed when extrapolated (note that for the Vendicari site results derive from boulders). Historical tsunamis dates are plotted with vertical red lines proportional to the known inundation extent along the coast (dashed when inundation sites are unknown, e.g., $365 \mathrm{AD}$ tsunami), while vertical hazel bars show the hypothesized best fitting age ranges for unknown tsunamis.

if not null. The 1783 and $17 \mathrm{AD}$ tsunami deposits were found only at Torre degli Inglesi site (at the northern tip of Sicily) and are likely related to a source located near Scilla (Fig. 2, on the Tyrrhenian coast of Calabria - see Bozzano et al., 2011). It is not surprising that the geological traces of these small events were not found anywhere else along the eastern coast of Sicily, being unlikely for a relatively small source to generate waves able to travel much across the Messina Straits preserving a sufficient power to inundate the land, bringing in a sizable amount of debris to be identified in cores as the geological signature of the tsunami itself.

Finally, we should comment on the 1542 tsunami that, being close in time and location to the 1693 regional event, could be easily overprinted both in terms of sediments and ages. A deposit that could be related to the 1542 tsunami was found at the Anguillara site (T3 in Fig. 6), ca. $70 \mathrm{~km}$ north of the area indicated as flooded in the contemporary reports (Augusta, see Figs. 2 and 6). At the other sites of Gurna, Augusta offshore and Priolo there is only evidence for one event (GUR-T1, AuOFF-E2 and PR-01, Fig. 6) in the time interval including both 1542 and 1693 . We consider more likely the fact that these traces are related to the larger 1693 tsunami.

As for the regional historical tsunamis, geological traces of the 1908 event were found at 5 sites (ANG-T1, AuOFFE1, Maddalena P., VEN-01 and MOR-T1, Fig. 6) for a total minimum inundated coastline extent of ca. $160 \mathrm{~km}$. The 
1908 geological record comprises both sandy-bioclastic layers and boulders and can be interpreted as evidence for very energetic waves. Similarly, the 1693 tsunami was recognised at 7 sites (GUR-T1, ANG-T2, AuOFF-E2, Magnisi P., PR01, Maddalena P., and Ognina) suggesting that the hit coastline was at least $130 \mathrm{~km}$-long. Also in this case, the evidence for the 1693 tsunami includes both coarse sand layers and megaclasts. Finally, the 1169 tsunami seems to duplicate the 1693 event, being found at 3 sites (GUR-T2, AuOFF-E3 and Ognina, Fig. 6), both as coarse sediments and boulders, reaching a total minimum hit shore length of $130 \mathrm{~km}$.

Similarly to the regional tsunamis presented above, traces of the $365 \mathrm{AD}$ basin-wide event were detected at 5 sites (GUR-T3, AuOFF-Ex, PR-02, Ognina and MOR-T2, Fig. 6) for a total minimum coastline length of ca. $160 \mathrm{~km}$, comparable with the 1908 tsunami. Differently, signatures of the ca. 1600 BC Santorini tsunami were found only in the Augusta Bay (AuOFF-E11 and PR-04, Fig. 6). In spite of the fact that this should have been a huge event, its evidence is limited at two sites likely because of the difficulty in reaching in the cored sediments an age comparable to that of Santorini eruption (Fig. 6).

Exploring the most obvious age correlations among those tsunami deposits that are not reported in the historical records (because lost or pre-historical) it is clear that most of the information is derived from the Augusta Bay area that contains the three sites (Augusta, Augusta offshore and Priolo) that are certainly the most outstanding in the region. These correlations are shown as vertical hazel bars in Fig. 6 .

As for the BC period, we found two potentially unknown tsunamis that hit the Augusta Bay: one event dated at 975$800 \mathrm{BC}$ (AU-02 and AuOFF-E10) and the other dated at $700-500 \mathrm{BC}$ that was potentially recorded at 3 sites (AU-01, AuOFF-E8 and PR-03, Fig. 6). For these two events it is not possible to confidently set a regional importance, because of the limited number of sites exploring through this age and, thus, we are forced to consider them as local events.

Surprisingly, one unknown tsunami was discovered also in the $\mathrm{AD}$ period in the age range $650-770 \mathrm{AD}$ at 4 sites (GUR-T2, AU-00, AuOFF-E4 and VEN-02) implying at least $145 \mathrm{~km}$ of coastline affected. If compared to the events discussed above $(1908,1693,1169)$, this tsunami would have to have a regional significance and, being a "missed" event in the historical dataset, may turn out to have also a basin-wide importance if found at other sites in the Mediterranean sea.

Summarizing these results, we note that local tsunamis are very difficult to capture and investigate with a geological approach. This is mainly due to two reasons: (1) they may have hit only relatively short portions of the coastline (10 to $40 \mathrm{~km}$ at the most) that may rarely include the geomorphological trap needed for sediments deposition and preservation, and (2) they are usually characterised by an inundation distance often comparable to the storm one, thus, being also under the influence of significant coastal erosional and depositional processes. Merging the tsunami data related to strong

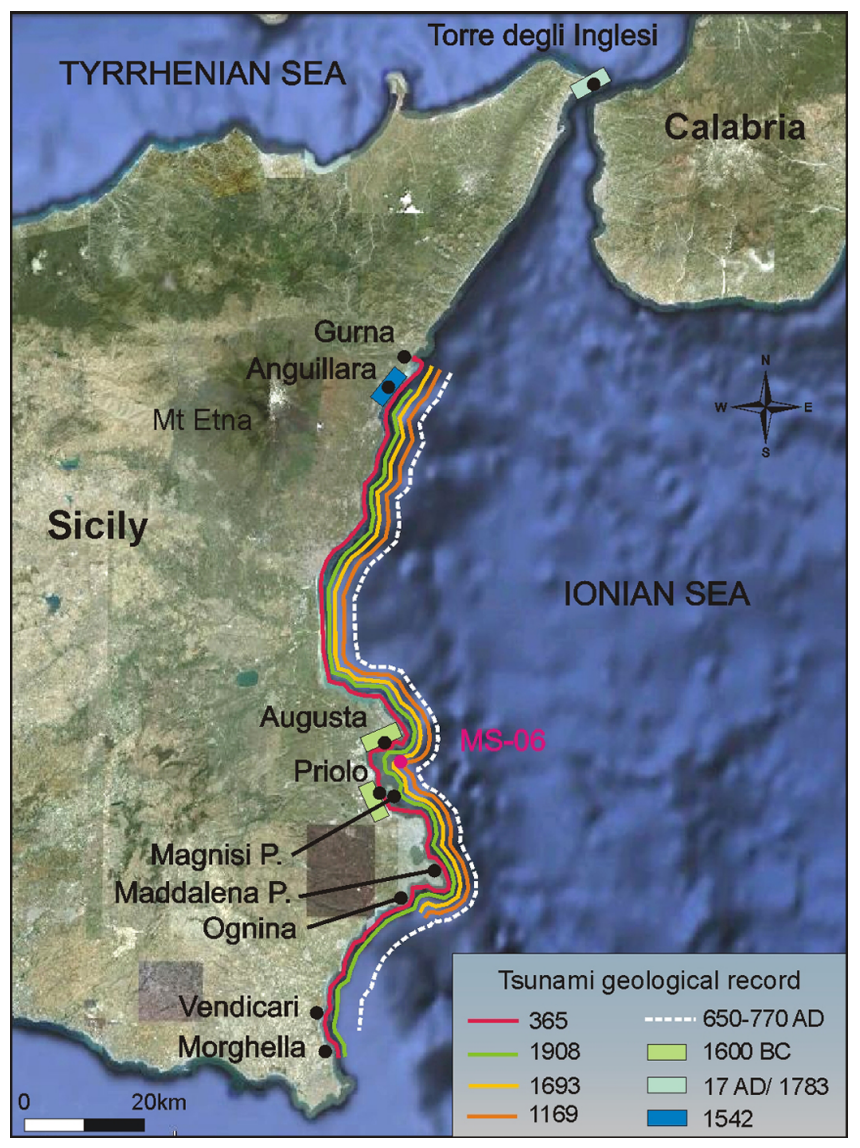

Fig. 7. Tsunamis geological record. Google Earth map of eastern Sicily synthesizing the portion of the coast hit by different tsunamis as coloured full lines, whereas the dashed line marks the coast inundated by the largest unknown tsunami. Rectangles indicate the portions of coast inundated by local events (see legend for age correlation). Names of sites are the same as in Fig. 2.

events (1908, 1693, 1169, 650-770 AD and 365 AD Crete), we found that they were potentially recorded at a minimum of 3 (1169) up to maximum 7 (1693) sites always hitting a long portion of the coast from 130 up to $160 \mathrm{~km}$ (Fig. 7). Thus, based on the number of sites and the length of affected coastline, we can rate them as of regional importance, aware of the fact that historical data and further geological researches will potentially increase their significance even at a basin-wide scale (as it is for the $365 \mathrm{AD}$ Crete tsunami, see De Martini et al., 2010; Smedile et al., 2011; Gerardi et al., 2012 for more details). It must be noticed that we also searched for tsunami deposits in many other sites (particularly near Messina and Catania towns), but significant urbanization of the past century together with paucity of favourable environments acting as sediment traps, played an important role in preventing us from identifying any tsunami traces.

For tsunami hazard purposes it is also relevant to compare the historical reports on the inundation distance from the present shoreline with the geologically observed values, 
considering the influence of tectonic vertical changes or sea-level rise on the shoreline position negligible in the approximate $300 \mathrm{yr}$ long time frame investigated. For the 1908 tsunami, the comparison can be done, for instance, at the Anguillara and Vendicari-Morghella sites where we observed the 1908 deposit at a distance of 280 and $380 \mathrm{~m}$ from the present shoreline, respectively, whereas at localities within ca. $15 \mathrm{~km}$ historical reports account for 200 and $15 \mathrm{~m}$, respectively (Platania, 1909; Baratta, 1910). The 1693 tsunami was reported (Boccone, 1697) to have inundated the Gurna-Anguillara area for $1500 \mathrm{~m}$ inland, whereas our geological data yield a minimum of $380 \mathrm{~m}$, and the Augusta Bay area for $165 \mathrm{~m}$ (Bottone, 1718), whereas at the Priolo site we found tsunami deposits up to $530 \mathrm{~m}$ inland.

\section{Conclusions}

By integrating geological data on paleotsunami deposits discovered at 11 distinct sites along the ca. $230 \mathrm{~km}$-long coast of eastern Sicily, we reconstructed the geological tsunami inundations history of the region, substantially extending back in time the historical record (Tables 1 and 2).

Based on 38 distinct tsunami deposits (from fine sand to boulders) and thanks to several chronological constraints obtained from different methodologies (archeology, radiocarbon dating, short-lived radionuclides, optically stimulated luminescence and tephrochronology), for the sites investigated we calculated a refined average tsunami recurrence interval that ranges between 320 and $840 \mathrm{yr}$.

The integration of these data with the historical accounts allowed us relating several tsunami deposits to known historical events (Fig. 6), including those originated far to the east (the 365 AD Crete and ca. 3600 BP Santorini basin-wide events) and highlighted the occurrence of some unknown tsunami inundations.

Moreover, the comparison of the ages of these events together with the location of the relative site of investigation along the coastline of eastern Sicily (Fig. 7) allowed us discriminating between tsunamis characterised by a relatively short length of inundated coast $(<40 \mathrm{~km})$ and those characterised by a long affected coastline $(>130 \mathrm{~km})$ that can be rated as of regional importance.

The geological record of local tsunamis resulted very difficult to be found. In fact, among the six events known from historical sources (17 AD, 1329, 1542, 1783, 1818 and 1990 tsunamis), we found traces of three of them (17 AD, 1542 and 1783) and only at one site (Fig. 7). We suspect that the characteristics of these tsunamis (e.g., reduced inland penetration, short hit coastline) may significantly reduce the possibility to leave and have preserved a recognisable deposit inland.

Differently, for the historically known regional events (1908, 1693, 1169), their geological evidence suggests that they share the potential to hit up to $70 \%$ of the entire coast of eastern Sicily.

Moreover, it was possible to suggest the occurrence of two local unknown tsunamis in the Augusta Bay area during the first millennium $\mathrm{BC}$ and, quite surprisingly, of one regional unknown tsunami, occurred in the age interval 650-770 AD. The latter was identified and characterised at 4 different sites for a minimum affected coast length of $145 \mathrm{~km}$.

By including this latter tsunami in the dataset presented above, we can estimate an eastern Sicily average recurrence interval for strong tsunamis of ca. $385 \mathrm{yr}$ in the past $2 \mathrm{ka}$.

Furthermore, the comparison between the historical inundation distance from the shore at few specific sites and the geologically observed minimum values suggests that the historical data tend to underestimate the tsunami ingressions, also by an order of magnitude.

Finally, after this work, we do believe even stronger than before that the combination of historical and geological data can be very effective in reconstructing the tsunami history of eastern Sicily as well as in providing robust parameters to be used in tsunami hazard estimate and scenario modelling.

Acknowledgements. This work was funded by the Italian Dipartimento della Protezione Civile in the frame of the 2007-2009 agreement with Istituto Nazionale di Geofisica e Geofisica e Vulcanologia - INGV and with contribution of the EU Transfer Project STREP n. 037058. We have to warmly thank F. Gerardi for her enthusiastic and productive collaboration in most of the investigations discussed in the present work. We are also indebted to P. Guarnieri, M. Cosentino, and the students F. Bombaci, G. Fazio, M. C. Marzullo, F. La Rosa and M. Raniolo that helped us in the field and in several discussions. Thanks also to P. Sansò and an anonymous reviewer for their suggestions that contributed to improve the original manuscript.

Edited by: S. Tinti

Reviewed by: two anonymous referees

\section{References}

Atwater, B. F. and Hemphill-Haley, E.: Preliminary estimates of tsunami recurrence intervals for great earthquakes of the past 3500 years at Northeastern Willapa Bay, Washington, US Geological Survey Open-File Report, 96-001, 1996.

Atwater, B. F. and Moore, A. L.: A tsunami about 1000 years ago in Puget Sound, Washington, Science, 258, 1614-1617, 1992.

Baratta, M.: La catastrofe sismica calabro-messinese (28 Dicembre 1908). Relazione alla, Soc. Geogr. Ital., Roma, 426 pp., 1910.

Barbano, M. S., De Martini, P. M., Pantosti, D., Smedile, A., Del Carlo, P., Gerardi, F., Guarnieri, P., and Pirrotta, C.: In search of tsunami deposits along the eastern coast of Sicily (Italy): state of the art, in: Recent Progress on Earthquake Geology, edited by: Guarnieri, P. P., Nova Science Publishers, 109-146, 2009.

Barbano, M. S., Pirrotta, C., and Gerardi, F.: Large boulders along the south-eastern Ionian coast of Sicily: storm or tsunami deposits?, Mar. Geol., 275, 140-154, 2010. 
Boccone, P.: Intorno il terremoto della Sicilia seguito l'anno 1693, Museo di Fisica, Venezia, IT, 1-31, 1697.

Boschi, E., Guidoboni, E., Ferrari, G., Gasperini, P., Mariotti, D., and Valensise, G.: Catalogue of strong earthquakes in Italy from 461 B.C. to 1997, Ann. Geof., 43, 843-868 and CD-ROM, 2000.

Bottone, D.: De immani Trinacriae terraemotu, Idea historicophysica, in qua non solum telluris concussiones transactae recensentur, sed novissimae anni 1717, Messina, IT, 1718.

Bozzano, F., Lenti, L., Martino, S., Montagna, A., and Paciello, A.: Earthquake triggering of landslides in highly jointed rock masses: Reconstruction of the 1783 Scilla rock avalanche (Italy), Geomorphology, 129, 294-308, 2011.

De Martini, P. M., Barbano, M. S., Smedile, A., Gerardi, F., Pantosti, D., Del Carlo, P., and Pirrotta, C.: A 4000 yr long record of tsunami deposits along the coast of the Augusta Bay (eastern Sicily, Italy): paleoseismological implications, Mar. Geol., 276, 42-57, doi:10.1016/j.margeo.2010.07.005, 2010.

Dominey-Howes, D. T. M.: A re-analysis of the Late Bronze Age eruption and tsunami of Santorini, Greece, and the implications for the volcano-tsunami hazard, J. Volcan. Geotherm. Res., 130, 107-132, 2004

Fujiwara, O. and Kamataki, T.: Tsunami depositional processes reflecting the waveform in a small bay: interpretation from the grain-size distribution and sedimentary structures, in: Tsunamiites - Features and Implications, edited by: Shiki, T., Tsuji, Y., Yamazaki, T., and Minoura, K., Elsevier, Amsterdam, 133-152, 2008.

Gelfenbaum, G. and Jaffe, B.: Erosion and sedimentation from the 17 July 1998 Papua New Guinea tsunami, Pure Appl. Geophys., 160, 1969-1999, 2003.

Gerardi, F., Barbano, M. S., De Martini, P. M., and Pantosti, D.: Discrimination of Tsunami Sources (Earthquake versus Landslide) on the Basis of Historical Data in Eastern Sicily and Southern Calabria, Bull. Seismol. Soc. Am., 98, 2795-2805, 2008.

Gerardi, F., Smedile, A., Pirrotta, C., Barbano, M. S., De Martini, P. M., Pinzi, S., Gueli, A. M., Ristuccia, G. M., Stella, G., and Troja, S. O.: Geological record of tsunami inundations in Pantano Morghella (south-eastern Sicily) both from near and far-field sources, Nat. Hazards Earth Syst. Sci., 12, 1185-1200, doi:10.5194/nhess-12-1185-2012, 2012.

Goto, K., Chagué-Goff, C., Fujino, S., Goff, J., Jaffe, B., Nishimura, Y., Richmond, B., Sugawara, D., Szczuciński, W., Tappin, D. R., Witter, R. C., and Yulianto, E.: New insights of tsunami hazard from the 2011 Tohoku-oki event, Mar. Geol., 290, 46-50, 2011.

Guidoboni, E., Comastri, A., and Traina G.: Catalogue of ancient earthquakes in the Mediterranean area up to the 10th century, Istituto Nazionale di Geofisica, Rome, IT, 504 pp., 1994.

Hutchinson, I., Clague, J. C., and Mathewes, R. W.: Reconstructing the tsunami record on an emerging coast: a case study of Kanim Lake, Vancouver Island, British Columbia, Canada, J. Coast. Res., 13, 545-553, 1997.
ISC, International Seismological Centre, On-line Bulletin, available at: http://www.isc.ac.uk/Bull/, Inter. Seismol. Cent., Thatcham, United Kingdom, 2004.

Jaffe, B. and Gelfenbaum, G.: Using tsunami deposits to improve assessment of tsunami risk. Solutions to Coastal Disasters '02, Conference Proceedings, 836-847, 2002.

Morton, R. A., Gelfenbaum, G., and Jaffe, B. E.: Physical criteria for distinguishing sandy tsunami and storm deposits using modern examples, Sed. Geol., 200, 184-207, 2007.

Okal, E. A. and Synolakis, C. E.: Source discriminants for near-field tsunamis, Geophys. J. Int., 158, 899-912, 2004.

Pantosti, D., Barbano, M. S., De Martini, P. M., and Smedile, A.: Geological evidence of paleotsunamis at Torre degli Inglesi (NE Sicily), Geophys. Res. Lett. 35, L05311, doi:10.1029/2007GL032935, 2008.

Paris, R., Fournier, J., Poizot, E., Etienne, S., Morin, J., Lavigne, F., and Wassmer, P.: Boulder and fine sediment transport and deposition by the 2004 tsunami in Lhok Nga (western Banda Aceh, Sumatra, Indonesia): A coupled offshore-onshore model, Mar. Geol., 268, 43-54, 2010.

Pinegina, T. K. and Bourgeois, J.: Historical and paleo-tsunami deposits on Kamchatka, Russia: long-term chronologies and longdistance correlations, Nat. Hazards Earth Syst. Sci., 1, 177-185, doi:10.5194/nhess-1-177-2001, 2001.

Platania, G.: Il Maremoto dello Stretto di Messina del 28 dicembre 1908, Boll. Soc. Sism. Ital., 13, 369-458, 1909.

Scicchitano, G., Monaco, C., and Tortorici, L.: Large boulder deposits by tsunami waves along the Ionian coast of south-eastern Sicily (Italy), Mar. Geol., 238, 75-91, 2007.

Scicchitano, G., Costa, B., Di Stefano, A., Longhitano, S. G., and Monaco, C.: Tsunami and storm deposits preserved within a riatype rocky coastal setting (Siracusa, SE Sicily), Z. Geomorphol., 54, Suppl. 3, 51-77, 2010.

Smedile A., De Martini, P. M., Pantosti, D., Bellucci, L., Del Carlo, P., Gasperini, L., Pirrotta, C., Polonia, A., and Boschi, E.: Possible tsunamis signatures from an integrated study in the Augusta Bay offshore (Eastern Sicily-Italy), Mar. Geol., 281, 1-13, 2011.

Soloviev, S. L., Solovieva, O. N., Go, C. N., Kim, K. S., and Shchetnikov, N. A.: Tsunamis in the Mediterranean Sea 2000 B.C.2000 A.D., Kluwer Academic Publishers, Dordrecht, 237 pp., 2000.

Stiros, S. C.: The AD 365 Crete earthquake and possible seismic clustering during the fourth to sixth centuries AD in the Eastern Mediterranean: a review of historical and archaeological data, J. Struct. Geol., 23, 545-562, 2001.

Tinti, S., Maramai, A., and Graziani, L.: The Italian Tsunami Catalogue (ITC), Version 2, available at: http://roma2.rm.ingv.it/ it/facilities/data_bases/27/catalogue_of_the_italian_tsunamis (last access: October 2011), 2007.

Weiss, R. and Bahlburg, H.: A note on the preservation of offshore tsunami deposits, J. Sediment. Res., 76, 1267-1273, 2006. 